\title{
Present Status of Erwinia amylovora in the Republic of North Macedonia
}

\author{
S. Mitrev ${ }^{*}$, B. Kovacevik, E. Arsov \\ Faculty of Agriculture, Goce Delcev University, Stip, Republic of North Macedonia.
}

How to cite this paper: S. Mitrev, B. Kovacevik, E. Arsov. (2020) Present Status of Erwinia amylovora in the Republic of North Macedonia. International Journal of the Science of Food and Agriculture, 4(4), 390-397.

DOI: $10.26855 /$ ijfsa.2020.12.005

Received: August 26, 2020

Accepted: September 28, 2020

Published: October 22, 2020

*Corresponding author: S. Mitrev, Faculty of Agriculture, Goce Delcev University, Stip, Republic of North Macedonia.

Email: sasa.mitrev@ugd.edu.mk

\begin{abstract}
This study aims to give an overview of the status of Erwinia amylovora, isolated from pear (Pyrus communis), wild pear (Pyrus pyraster), apple (Malus silvestris), and quince trees (Cydonia oblonga) from different localities in the Republic of North Macedonia, for the period 2015-2019. Classical biochemical analyses coupled to modern molecular diagnostic tools such as PCR and Real Time PCR were used for the determination of bacteria. Symptomatic fruit trees were noticed in almost all investigated localities in Republic of North Macedonia. The most expressed symptoms were recorded during the intensive growth of the shoots. Isolated strains elicited HR in tobacco, necrosis of pear seedlings, and immature pear fruits. Strains possess typical biochemical characteristics compared with the positive control, such as non-fluorescent, anaerobic (oxidase negative), levan production, and catalase enzymatic activity, doesn't hydrolyze gelatine, aesculin, and starch, produce acid from sucrose, fructose, and galactose, etc. Amplification of the total bacterial DNA originating from apple, pear, wild pear, and quince trees using PCR followed by agarose electrophoresis, showed that PCR patterns for all investigated native strains are identical to the European reference strain (LMG 1883). TaqMan qPCR was used to quantify E. amylovora DNA from different host plants and locations, during the investigated period. The results indicate that the disease incidence is sporadic and crop damages are of medium economic significance. E. amylovora in the Republic of North Macedonia was identified as a causal agent of fire blight on pear, wild pear, apple, and quince trees in young and old fruit orchards.
\end{abstract}

\section{Keywords}

Biochemical characteristics, PCR, Real Time PCR

\section{Introduction}

Bacterial blight, caused by Erwinia amylovora, is an economically important bacterial disease of apples and pears which is present in North America, most countries in Western Europe, large areas around the Mediterranean Sea, and New Zealand [1]. This bacteria is responsible for serious economic losses in countries where it has appeared. It is assumed that the disease was first recognized in the United States at the end of the 18th century (1780) in wild species of plants, from which the bacteria spread to sensitive varieties of pear (Pyrus communis), apple (Malus silvestris), and quince (Cydonia oblongata), introduced by early American settlers from Eastern Europe and Southwest Asia [2]. Drying of fruit trees was first observed in mountainous areas on both sides of the Hudson River in New York. From this region, the bacteria spread rapidly to the neighboring countries. According to Harrison (1904), the disease was present in Canada since 1840 and spread to many areas in the province of Ontario in 1870. The pathogen was noticed in New Zealand in 1919 [1]. It has spread across the Pacific and appeared in Japan, affecting seedlings first, and later affecting apple trees [3]. In 1976, a loss of $\$ 4.7$ million was reported in California, mainly affecting pears. In 1991, a loss of 
about 3.8 million dollars was reported in Southwest Michigan [4]. It is estimated that the epidemic which occurred in southwest Michigan in 2000 caused damage of approximately $\$ 42$ million [5]. The first report about the presence of $E$. amylovora in Mexico date from 1921, and in 1943 was observed in pear and apple trees [1]. In Egypt in 1988, the bacteria destroyed $80 \%$ of pear trees, with around $50 \%$ of the crop uprooted [1]. Even in areas where climatic conditions are generally not favorable for the development of bacterial blight epidemics, the disease may arise from time to time, such as in the UK in the early 1980s [6]. Three factors contribute to the high economic importance of Erwinia amylovora: the ability of bacteria to multiply on the surface of the plants without causing a disease, the ability to be easily transported by insects, wind, and rain and spread relatively quickly over short distances and the third factor is the inherent difficult control of the disease [7]. Based on its economic importance and the level of threat to fruit and ornamental plants, the bacteria have been designated as a quarantine organism in many countries. After World War II, devastating damages occurred in all regions where the presence of bacteria was reported. Therefore, its rapid appearance was expected in Europe. England was the first country in Europe where the disease was noticed in 1957 [8]. The first symptoms of fire blight in the Republic of North Macedonia were noticed in 1986 in commercial quince and pear orchards near the border of Greece and the locality of Radovish ( $45 \mathrm{ha}$ ), respectively. Next two years, the disease spread to the commercial pear orchards on the territory of Gevgelija (33 ha), Negotino and Strumitsa, and then in the Vinitsa region destroying the pear orchards. Mild winters and almost Mediterranean climate in the country contribute to a rapid spread of the disease and by the end of 1990, it was detected in 252 ha of pear and 44 ha of quince orchards. Next two years the disease expanded in 500 ha of pear and 60 ha of quince trees and occupies municipalities like Bitola, Gevgelija, Gostrivar, Ohrid, Vinitsa, Veles, Kavadarci, Kriva Palanka, Negotino, Probishtip, Radovish, Strumitsa, Skopje, and Shtip [9]. At that time, the disease was rarely present on apple and it was found only on several individual apple trees and hawthorn (Crategus spp.), too. Around 700,000 diseased trees from around 400 ha of pear and 60 ha of quince orchards were eradicated and the total damage was estimated at 10,000,000 DEM [9].

Recent studies by Mitrev and Kostadinovska [10] have shown renewed interest in Macedonia over bacterial blight in the wild population of pear. In the scientific community, there is an opinion that wild varieties of pear are sources of genes of resistance to pathogenic organisms, but Mitrev and Kostadinovska demonstrated that E. amylovora attacks wild pear in the country. Isolates from wild pear were identified using conventional methods and modern (molecular) methods of identification. In their research, authors observed that E. amylovora spread in the whole investigated area in N. Macedonia and that the greatest damage was induced by affecting the wild pear [10].

\section{Material and methods}

\subsection{Isolation and identification of the pathogen}

In the period 2015/19, seven different locations in the Republic of North Macedonia were observed and symptomatic samples (Figure 2 and Figure 3) were collected for future analyses, to confirm the present status of E. amylovora (Table 1). Small pieces of the samples were surface sterilized using $0.5 \%$ sodium hypochlorite, rinsed three times with sterile distilled water (SDW), placed in a sterile mortar, and grounded with a pestle in $0.5 \mathrm{ml}$ of SDW. The resulting suspension was left to stand for $10 \mathrm{~min}$, and then $100 \mu \mathrm{l}$ were plated on sucrose nutrient agar (NAS) medium [11]. Inoculated plates were incubated at $25 \pm 1^{\circ} \mathrm{C}$ until bacterial colonies developed on the plate surfaces (around 48 hours). White-domed colonies were subcultured several times on NAS medium until purification of the cultures and kept at $4^{\circ} \mathrm{C}$ for further identification. From the total number of 106 isolates, 20 were used for complete biochemical analyzes (Table 1). Reference isolates were maintained in $20 \%$ glycerol at $-80^{\circ} \mathrm{C}$.

\subsection{Growth of the bacterium}

All strains were assayed for growth on sucrose nutrient agar (NAS) medium [11], King's medium B agar (KB) [12] and on Crystal violet-cycloheximide-tergitol (CCT) medium [13]. The characteristics of the colonies grown on these media were recorded 48 and $72 \mathrm{~h}$ after incubation and the experiment was repeated twice.

\subsection{Pathogenicity test on immature pear fruit and leaves}

Immature healthy fruits and leaves of a highly susceptible cultivar, pear (Pyrus communis) $1.5-2 \mathrm{~cm}$ in diameter were collected, surface sterilized with $0.5 \%$ sodium hypochlorite, and rinsed three times with SDW. Each immature pear fruit and leaves were stab inoculated with a needle using sterile distillate water as a negative control or a bacterial suspension of $10^{9}$ colony forming units (CFU)/mL, which was prepared from a $24^{\mathrm{h}}$-old bacterial culture. Inoculated fruits and leaves were kept in a moist chamber at $26 \pm 1^{\circ} \mathrm{C}$ and checked daily for the presence of necrosis accompanied by bacterial oozing, which was considered a positive indicator for E. amylovora. Leaves were stained in a glass erlenmeyer flask with sterile agar inside. For each isolate, the experiment was repeated two times, using three pear fruits and leaves which were kept separately. Isolates Ks550 (Kavadarci, Mk) and LMG1883 (Belgium collection) were used as positive controls for E. amylovora (Table 1). 
Table 1. Review of isolates obtained from different fruit species collected from different localities in N. Macedonia

\begin{tabular}{|c|c|c|c|c|c|}
\hline No & Isolate code & Year of isolation & Host plant & Region & Isolate \\
\hline 1 & DvEa-1 & 2015 & Pyrus communis & Valandovo, MK & Erwinia amylovora \\
\hline 2 & DvEa-2 & 2015 & Pyrus communis & Valandovo, MK & Erwinia amylovora \\
\hline 3 & DvEa-3 & 2015 & Pyrus communis & Valandovo, MK & Erwinia amylovora \\
\hline 4 & DvEa-4 & 2015 & Pyrus communis & Valandovo, MK & Erwinia amylovora \\
\hline 5 & DvEa-5 & 2015 & Pyrus communis & Valandovo, MK & Erwinia amylovora \\
\hline 6 & DdEa-1 & 2016 & Cydonia oblonga & Delchevo, MK & Erwinia amylovora \\
\hline 7 & DdEa-2 & 2016 & Cydonia oblonga & Delchevo, MK & Erwinia amylovora \\
\hline 8 & DdEa -3 & 2016 & Cydonia oblonga & Delchevo, MK & Erwinia amylovora \\
\hline 9 & DsEa-1 & 2017 & Cydonia oblonga & Shtip, MK & Erwinia amylovora \\
\hline 10 & DsEa-2 & 2017 & Cydonia oblonga & Shtip, MK & Erwinia amylovora \\
\hline 11 & DkEa-1 & 2017 & $\begin{array}{l}\text { Pyrus pyraster } \\
\text { (wild pear) }\end{array}$ & Saramzalino, MK & Erwinia amylovora \\
\hline 12 & DkEa-2 & 2017 & $\begin{array}{l}\text { Pyrus pyraster } \\
\text { (wild pear) }\end{array}$ & Saramzalino, MK & Erwinia amylovora \\
\hline 13 & DkEa-1 & 2018 & Malus silvestris & Kochani, MK & Erwinia amylovora \\
\hline 14 & DkEa-2 & 2018 & Malus silvestris & Kochani, MK & Erwinia amylovora \\
\hline 15 & DsrEa-1 & 2019 & Cydonia oblonga & Strumitsa, MK & Erwinia amylovora \\
\hline 16 & DsrEa-2 & 2019 & Cydonia oblonga & Strumitsa, MK & Erwinia amylovora \\
\hline 17 & DsrEa-3 & 2019 & Cydonia oblonga & Strumitsa, MK & Erwinia amylovora \\
\hline 18 & DsrEa-4 & 2019 & Cydonia oblonga & Strumitsa, MK & Erwinia amylovora \\
\hline 19 & DrEa-1 & 2019 & Malus silvestris & Resen, MK & Erwinia amylovora \\
\hline 20 & DrEa-2 & 2019 & Malus silvestris & Resen, MK & Erwinia amylovora \\
\hline 21 & $\underset{\text { (referent isolate) }}{\text { Ks-550 }}$ & 1991 & Pyrus communis & Kavadarci, MK & Erwinia amylovora \\
\hline 22 & $\underset{\text { (referent isolate) }}{\mathbf{L M G 1 8 8 3}}$ & 1980 & Pyrus communis & Belgium & Erwinia amylovora \\
\hline
\end{tabular}

\subsection{Hypersensitive response on tobacco}

Bacterial isolates were grown overnight in a liquid broth (LB) medium, pelleted cells were diluted in $1 \times$ PBS to $10^{9}$ $\mathrm{CFU} / \mathrm{ml}$ and infiltrated with a syringe into tobacco leaves (cv. Samsun). The plants were then incubated in a growth chamber at $25 \pm 1^{\circ} \mathrm{C}$ using $16 \mathrm{~h}$ illumination and $80 \%$ humidity, and readings were taken after $24,48,72$, and 96 hours. $E$. amylovora isolates LMG1883 and Ks550 were used as positive controls and PBS was used as a negative control.

\subsection{BIOLOG test}

BIOLOG GN/GP MicroPlate system was used for testing the utilization of 95 carbon sources. The results from the BIOLOG system were analyzed using the compatible software, Microlog ${ }^{\mathrm{TM}}$ version 4.20.05.

\subsection{Chromosomal DNA isolation}

For the molecular testing, a single colony from a 24-hour NA or NAS culture, grown overnight at $25 \pm 1^{\circ} \mathrm{C}$, was suspended in $0.5 \mathrm{ml}$ of molecular grade sterile water in a microcentrifuge tube and used directly in the PCR mix [14]. 


\subsection{PCR assays}

The temperature of the initial denaturation step of the amplification cycle adequately lysed the bacterial cells, making the target genome accessible to the PCR primers and polymerases. The conventional (or single) PCR was performed using primer sequences (primer A: 5' CGG TTT TTA ACG CTG GG 3' and primer B: 5’ GGG CAA ATA CTC GGA TT 3'), based on the plasmid pEA29 DNA and conditions described by Bereswill et al. [15]. The PCR reaction mixture $(50 \mu \mathrm{l})$ contained a final concentration of $10 \times$ PCR buffer, $10 \mathrm{mM}$ of each dNTP, $50 \mathrm{mM} \mathrm{MgCl}$ 2, formamide, $10 \mathrm{pmol}$ $\mathrm{\mu l}^{-1}$ of each primer, $5 \mathrm{U} \mathrm{ul}^{-1}$ Taq polymerase, and $5 \mu \mathrm{l}$ of template DNA. The reaction conditions were a denaturation step at $93^{\circ} \mathrm{C}$ for 5 minutes, followed by 40 cycles of 30 seconds each at $93^{\circ} \mathrm{C}$ for denaturation, then 30 seconds at $52^{\circ} \mathrm{C}$ for annealing, $72^{\circ} \mathrm{C}$ for 75 seconds for the extension step, and a final step for 10 minutes at $72^{\circ} \mathrm{C}$ to finish the reaction.

\subsection{Real Time PCR}

Real-Time PCR, Taq-Man ${ }^{\circledR}$ technology was used for the quantification of E. amylovora from different host plants for the period 2015-2019. Real-Time PCR analyses were performed on a 7500 Real Time PCR system (Applied Biosystems) with 7500 software v 2.3, by using Taq-Man ${ }^{\circledR}$ Reagents. Total DNA was extracted by using PureLink Genomic DNA Mini Kit, as recommended in the user manual. Negative and positive controls from the detection kit for Erwinia amylovora were included. Eight out of ten representative samples were made from the stock DNA and used in qPCR master mix. Linear regression curves were obtained by plotting cycle threshold $(\mathrm{Ct})$ values of each reaction against the logarithmic values of E. amylovora units.

\section{Results and discussion}

\subsection{Isolation and identification of the causal agent}

During the period 2015/19, several localities in the Republic of North Macedonia were investigated for the presence of fire blight on pear (Pyrus communis), wild pear (Pyrus pyraster), apple (Malus silvestris), and quince (Cydonia oblonga) (Table 1). Symptomatology was typical for E. amylovora, in all parts and quince, pear, and apple trees in North Macedonia (Figures 1a and 1b). After isolation, colonies were kept at $4^{\circ} \mathrm{C}$ and tested with biochemical and molecular analyzes. From the total number of 106 isolates, 20 were laboratory tested for this research for biochemical analyses, and 10 positive randomly chosen samples by years from the different investigated localities were quantified with conventional PCR and TaqMan qPCR) compared with two positive controls (Ks550 and LMG1883).

\subsection{Pathogenicity test on immature pear fruit and leaves}

Isolates induced necrosis accompanied by yellowish bacterial exudate (oozing) on immature pear fruits and leaves after the incubation period of 3 days (Figures 4-1 and 4-2).

\subsection{Hypersensitive response on tobacco}

All tested isolates (20 representatives) developed a hypersensitive response (HR) on tobacco leaves (Nicotiana tabacum cv. Samsun) which occurs within 24 to 48 hours and induced production of typical necrosis on the leaves.

\subsection{BIOLOG test}

The results from the BIOLOG system were analyzed on compatible software, Microlog ${ }^{\mathrm{TM}}$ version 4.20 .05 , and results showed $100 \%$ presence of E. amylovora (with similarities between 0.916 and 0.959 ) compared with the positive control (similarity of 0.993).

\subsection{PCR amplification}

The PCR products from the conventional (single) PCR amplification, were separated on a $1.5 \%$ agarose gel in $0.5 \times$ TAE buffer for 20 minutes at $120 \mathrm{~V}$, then stained with $0.5 \mu \mathrm{g} \mathrm{ml}^{-1}$ ethidium bromide solution. The resulting gel was photographed under UV light. The region of the 16S rRNA gene (approximately 1,100 bp) was amplified for each of ten randomly chosen E. amylovora isolates using the universal primers A and B [14] and compared with the positive reference control (LMG 1883) (Table 2 and Figure 5).

\subsection{Real Time PCR}

The efficiency of the assay could be shown by analyzing a curve, and the specific product for Erwinia amylovora generates a specific FAM-labeled amplification curve (Figure 5). The $\mathrm{Ct}$ of the positive amplification curve was 24 (Ct $\leq 38$ for positive samples), and for the negative control, $\mathrm{Ct}$ was 45 (Ct $>40$ or no $\mathrm{Ct}$ for negative samples). Our positive samples have Ct between 22 and 24, and amplification starts between 14 and 20 cycle as shown in Figure 6. 


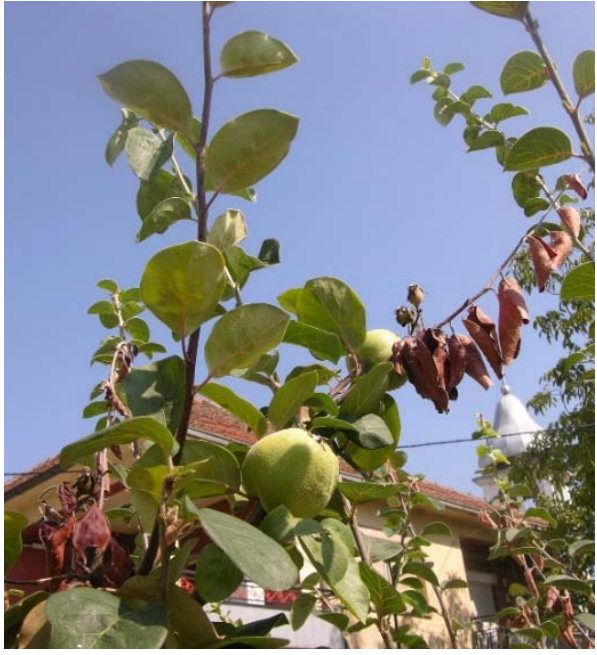

a.

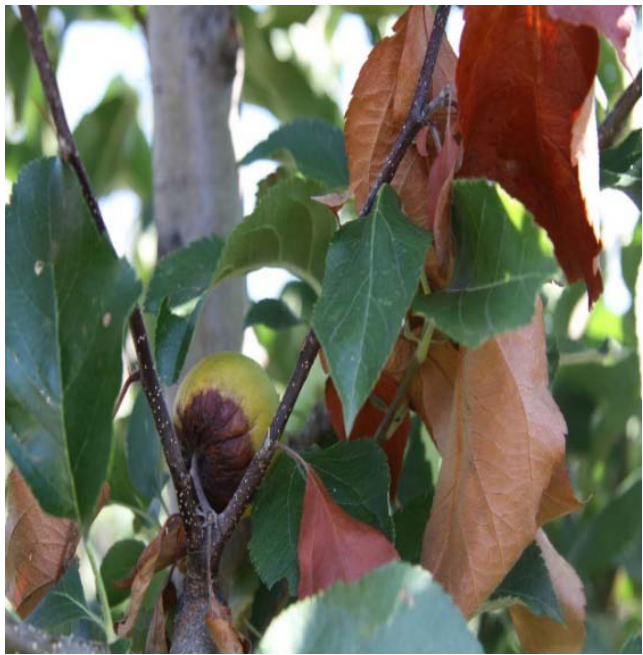

b.

Figure 1. Symptoms of "burnt plants" caused by E. amylovora: 1a. Typical symptoms with necrosis in the upper part (quince three in Strumitsa region); 1b. Symptoms on leaves on apple three in Kochani region.

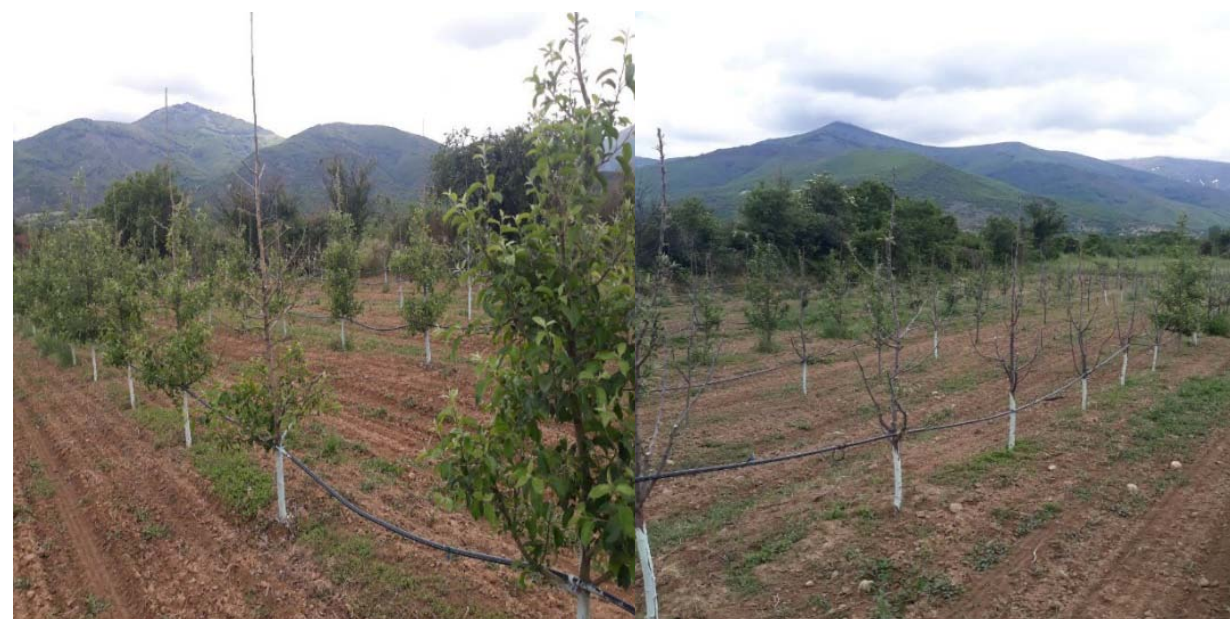

Figure 2. Young apple orchards (2016 year of planting) in regions near Resen locality (Krani KO 1709), Republic of North Macedonia, 2019 collection year.

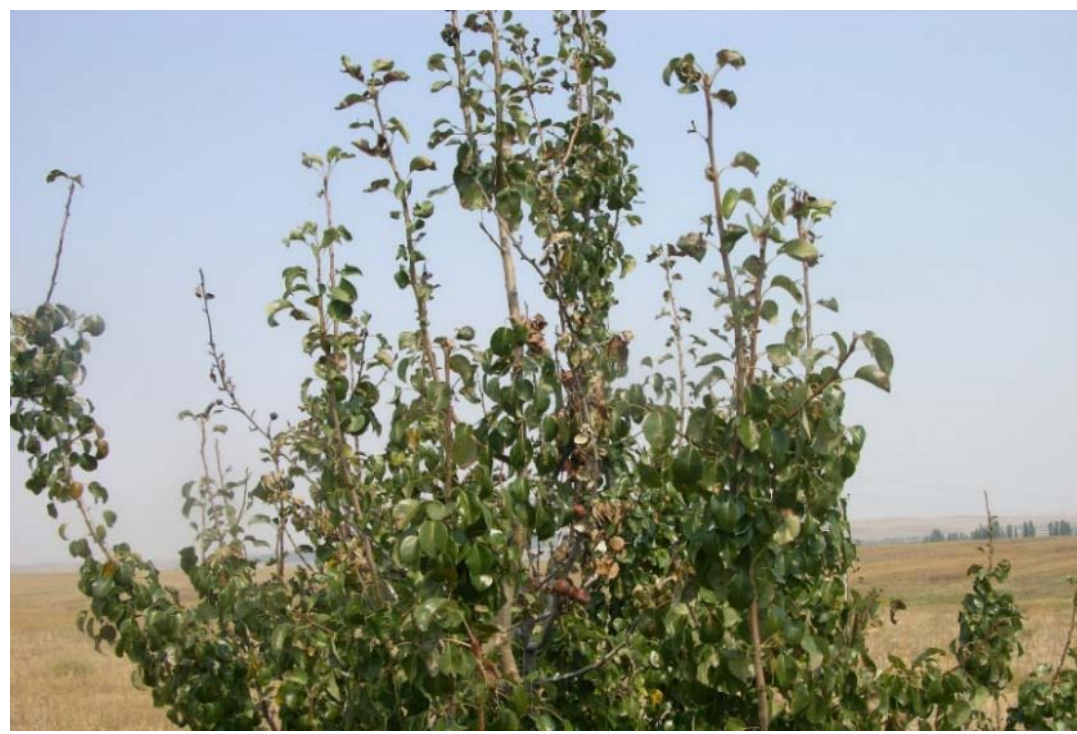

Figure 3. Symptoms caused by E. amylovora on wild pear (Pyrus pyraster). 


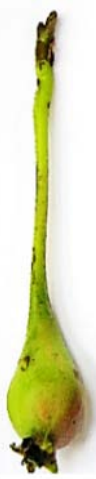

A

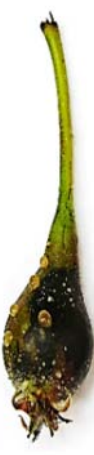

B

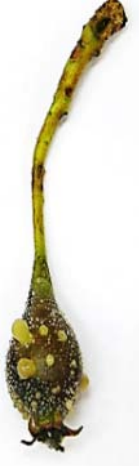

C

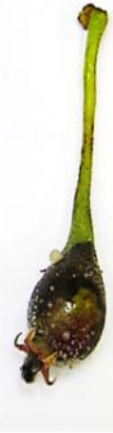

D

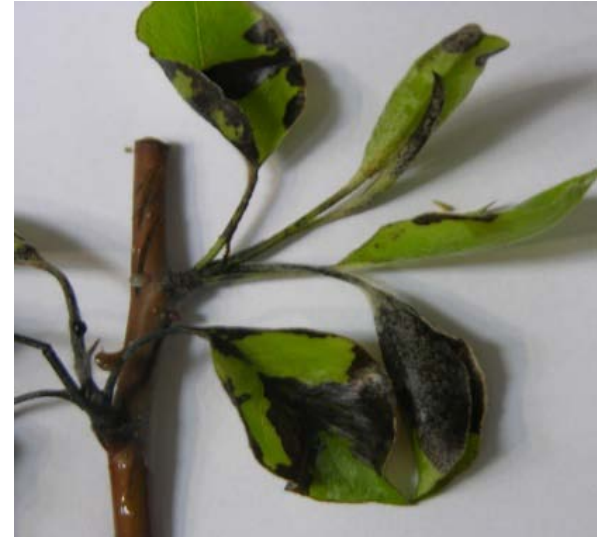

4-2

Figure 4-1. Immature pear fruits: A. Negative control (sterile distillate water); B. DrEa-1 isolate from Malus silvestris, Resen 2019; C. DsEa-2, isolate from Cydonia oblonga, Shtip, 2017; D. DvEa-5, isolate from Pyrus communis, Valandovo, 2015. Figure 4-2. Immature pear leaves with DdEa-3 isolate from Cydonia oblonga, Delcevo, 2016.

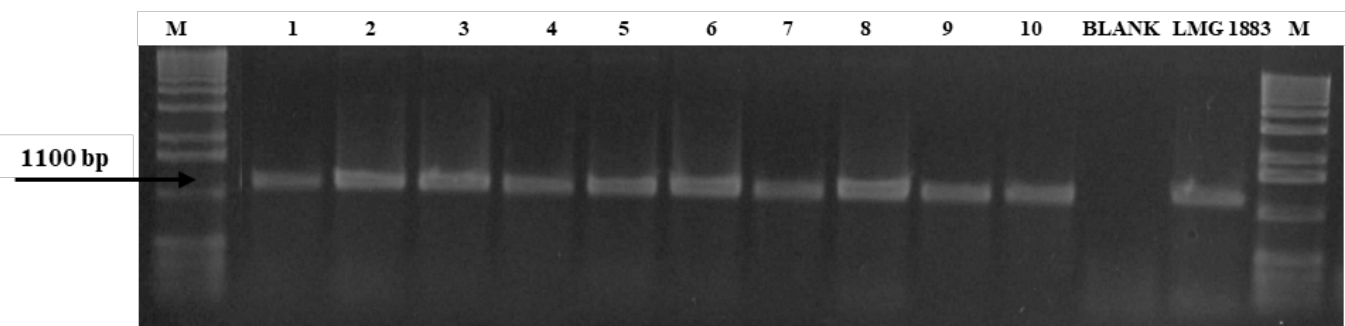

Figure 5. 1.5\% agarose gel electrophoresis showing a band pattern (1.1 kb) of the single PCR amplification product using primers $A$ and $B$.

The lane marked M contains the PCR markers ranging from $1 \mathrm{~Kb}$ DNA Ladder (NIPPON Genetics); lanes 1-10 contain isolates shown in Table 2; BLANK is a blank sample containing only molecular grade sterile water; the lane marked LMG1883 representative positive control from Belgium; lane marked M contains the PCR markers 1 Kb DNA Ladder (NIPPON Genetics).

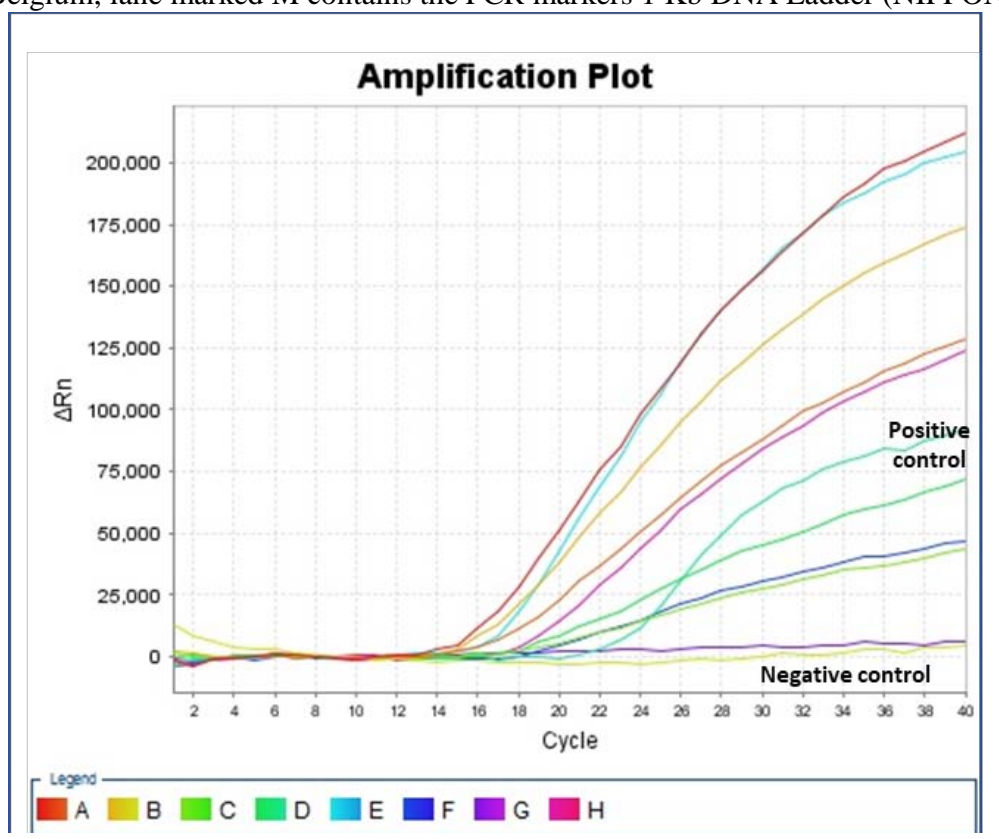

Figure 6. Amplification curves of $E$. amylovora infected samples from $\mathrm{A}$ to $\mathrm{H}$ and positive (infected Rosacae sample) and negative (healthy Rosacae sample) control.

(Code from the Table 1: A-DdEa-1; B - DsrEa-1; C - DkEa-1; D- DkEa-2; E - DvEa-1; F - DkEa-2; G - DrEa -1; H - DrEa - 2). 
Table 2. Representative samples chosen for conventional PCR and TaqMan qPCR for detection of the E. amylovora status during the period 2015-2019 in different host plants and regions in N. Macedonia

\begin{tabular}{|c|c|c|c|c|c|c|}
\hline $\mathbf{N b}$ & Isolate code & Year of isolation & Host plant & Region & $\begin{array}{c}\text { Conventional PCR } \\
\text { (Bereswill et al., 1992) }\end{array}$ & $\begin{array}{c}\text { TaqMan } \\
\text { qPCR }\end{array}$ \\
\hline 1 & DvEa-1 & 2015 & Pyrus communis & Valandovo, MK & + & + \\
\hline 2 & DvEa-2 & 2015 & Pyrus communis & Valandovo, MK & + & * \\
\hline 3 & DdEa-1 & 2016 & Cydonia oblonga & Delchevo, MK & + & + \\
\hline 4 & DdEa-2 & 2016 & Cydonia oblonga & Delchevo, MK & + & + \\
\hline 5 & DkEa-1 & 2017 & Pyrus pyraster (wild pear) & Saramzalino, MK & + & + \\
\hline 6 & DkEa-2 & 2017 & Pyrus pyraster (wild pear) & Saramzalino, MK & + & + \\
\hline 7 & DkEa-1 & 2018 & Malus silvestris & Kochani, MK & + & + \\
\hline 8 & DsrEa-1 & 2019 & Cydonia oblonga & Strumitsa, MK & + & + \\
\hline 9 & DrEa-1 & 2019 & Malus silvestris & Resen, MK & + & + \\
\hline 10 & DrEa-1 & 2019 & Malus silvestris & Resen, MK & + & $*$ \\
\hline+ & $\underset{\text { (referent isolate) }}{\text { LMG1883 }}$ & 1980 & Pyrus communis & Belgium & + & * \\
\hline
\end{tabular}

${ }^{*}$ not used in TaqMan qPCR

\section{Conclusion}

Fire blight disease is well known and much-observed disease affecting apple, pear, quince trees, and other species from the family Rosacae. The causal agent Erwinia amylovora is widely investigated and laboratory tested. This study aimed to give an accent to isolates from pear (Pyrus communis), wild pear (Pyrus pyraster), apple (Malus silvestris), and quince trees (Cydonia oblonga) from different localities in the Republic of North Macedonia, to check the status of the pathogen and what are the possibilities for spreading of the disease. Symptoms in the field were recognized as typical for E. amylovora, and from the total number of 106 isolates, only 20 isolates were obtained for complete biochemical analyses, and randomly were chosen 10 representatives for molecular analyses (conventional PCR and TaqMan Real Time PCR assays). This research gives an overview of the present status of Erwinia amylovora in different fruit cultures such as apple, pear, quince, and wild pear. The disease incidence is sporadic and the estimated crop damages were of medium economic significance. It is important to know that E. amylovora is present and spread not only in cultivated but also in wild pear (Pyrus pyraster). All isolates were shown to belong to E. amylovora based on morphology, culture, and biochemical, pathological, and molecular characteristics, including PCR analyses of the 16S rRNA gene (1,100 bp) and qPCR (Ct between 22 and 24).

\section{References}

[1] Bonn, W. G., Van der Zwet T. (2000). Distribution and economic importance of fire blight. In J. L. Vanneste (Ed.), Fire blight the disease and its causative agent, Erwinia amylovora. Wallingford: CABI Publishing, UK, pp. 37-53.

[2] Sanin, M., Misirli, A., Ozaktan, H. (2020). Determination of fire blight (Erwinia amylovora) susceptibility in Turkey’s Cydonia oblonga Mill. Germplasm. European Journal of Plant Pathology, volume 157, pp. 227-237.

[3] Uyeda, E. (1903). On the Causal Bacteria of Fire Bight of apple. Dai-Nippon Nokai-ho, 260: 1-3. (In Japanese).

[4] Smith, H. and Lattimore, R. (1997). The search for rules for non tariff barriers: fire blight of apples. International Agricultural Trade Research Consortium (IATRC) Meeting, San Diego, CA, USA, December 14-16, 1997. [online]. [http://researcharchive.lincoln.ac.nz/dspace/ bitstream/10182/872/1/cd_dp_44 .pdf].

[5] Longstroth, M. (2000). The 2000 fireblight epidemic in southwest Michigan. Michigan State University-extension, Van Buren County. http://www.canr.msu.edu/vanburen/fbdam.htm\#5yrloss [accessed 12 May 2008].

[6] Gwynne, D. C. (1984). Fire blight in perry pears and cider apples in the South West of England. Acta Horticulturae, 151: 41-47.

[7] Thomson, S. V. (2000). Integrated orchard and nursery management for the control of fire blight. In: Fire blight the disease and its causative agent, Erwinia amylovora [ed. by Vanneste JL] Wallingford, UK: CABI, 9-36.

[8] Crosse, J. E., Bennett, M., and Garrett, C. M. E. (1958). Fire blight on pear in England. Nature, 182: 1530-1530.

[9] Mitrev, S. (1993). Proučavanjebakterije Erwinia amyiovora (Burrill 1882) Winslow et al. 1920 kaoparazitavoćaka u Makedoni- 
ji. Magistarskateza. Novi Sad: Poljoprivrednifakultet - Institut za zaštitubilja.

[10] Mitrev, S. and Kostadinovska, E. (2013). Wild pear-Pyrus pyraster as a new host of Erwinia amylovora in Macedonia. Journal of Plant Pathology, 1(2): 167-170.

[11] Billing, E., Baker, L. A., Crosse, J. E., and Garrett, C. M. (1961). Characteristics of English isolates of Erwinia amylovora (Burrill). J Applied Bacteriol, 24: 195-211.

[12] King, E. O., Ward, M. K., and Raney, D. E. (1954). Two simple media for the demonstration of pyocyanin and fluorescein. Journal of Laboratory and Clinical Medicine, 44: 301-307.

[13] Ishimaru, C. and Klos, E. J. (1984). New medium for detection of Erwinia amylovora and its use in epidemiological studies. Phytopathology, 74: 1342-1345.

[14] Bereswill, S., Pahl, A., Bellemann, P., Zeller, W., and Geider, K. (1992). Sensitive and species-specific detection of Erwinia amylovoraby polymerase chain reaction analysis. Appl. Environ. Microbiol. 58: 3522-3526.

[15] Bereswill, S., Bugert, P., Bruchmuller, I., and Geider, K. (1995). Identification of the fire blight pathogen, Erwinia amylovoraby PCR assays with chromosomal DNA. Appl. Environ. Microbiol. 61: 2636-2642. 